\title{
Historical Review of Ulama and Umara' Relations and Its Implications for Islamic Da'wah
}

\author{
Mastori $^{1}$, Zenal Arifin ${ }^{2}$ \& Sunardi Bashri Iman ${ }^{3}$ \\ ${ }^{1}$ STAI PTDII Jakarta, Indonesia \\ ${ }^{2}$ Institut Pembina Rohani Islam Jakarta, Indonesia \\ ${ }^{3}$ STIUDIA Jakarta, Indonesia \\ *mastory87@gmail.com
}

\begin{abstract}
This study seeks to analyze the relationship between ulama and umara' and their implications for Islamic da'wah. The research was conducted by exploring historical and empirical sources related to the relationship between the ulama and umara' past and present which is reflected in the various political thoughts and policies of the ulama and umara'. The data was collected through observation and literature study while the data were analyzed using a descriptive qualitative approach. The results of the study show that historically the relationship between ulama and umara' occurred dynamically. During the past Islamic empires, the relationship between ulama and umara' was collaborative and even integrative. While in later times the relationship between ulama and umara' tended to be secularistic-pragmatic. The implication of this integrative relationship is that Islamic da'wah can develop rapidly so that Islam becomes the religion of the majority of the Indonesian people. Meanwbile, pragmatic secularistic relations made da'wah stagnant due to the weak involvement of umara' in the process of Islamization.
\end{abstract}

Keywords: Ulama; Umara'; relation; implication of da'wah.

\begin{abstract}
ABSTRAK
Penelitian ini berupaya untuk menganalisis relasi ulama dan umara' dan implikasiinya bagi dakwah Islam. Penelitian dilakukan dengan menggali sumber-sumber historis dan empiris terkait hubungan ulama dan umara' masa lalu dan saat ini yang tercermin dalam beragam pemikiran dan kebijakan politik ulama dan umara'. Pengumpulan data dilakukan melalui observasi dan studi pustaka sedangkan data dianalisis dengan pendekatan kualitatif deskripstif. Hasil penelitian menunjukan bahwa secara historis relasi ulama dan umara' terjadi secara dinamis. Pada masa kerajaan Islam masa lalu hubungan ulama dan umara' terjadi secara kolaboratif bahkan integratif. Sementara pada masa sesudahnya hubungan ulama dan umara' cenderung sekuleristik-pragmatik. Implikasi dari hubungan integratif adalah dakwah Islam dapat berkembang secara cepat sehingga Islam menjadi agama mayoritas rakyat Indonesia. Sementara hubungan sekuleristik pragmatik membuat dakwah stagnan karena lemahnya keterlibatan umara' dalam proses islamisasi.
\end{abstract}

Kata Kunci: Ulama; Umara'; relasi; implikasi dakwah 


\section{INTRODUCTION}

Functionally, da'wah requires two main supporting components, namely ulama and umara'. Both have a very strategic position in people's life. Through the religious knowledge possessed by the ulama, the society will be guided on the right path. Without the existence of ulama, society will lose the light that can guide it on the path of truth. Because the main function of the ulama is to maintain the upholding of the Islamic religion and be a guide for humans.

The strategic role occupied by the ulama is illustrated very clearly from a hadith of the prophet narrated by Imam Bukhari that when Allah will take knowledge from humans, the ulama will die. When many ulama die, the people will lose a place to ask questions. Finally, they ask to the stupid people who answer human questions without a scientific basis. As a result, the answer is misguided and misleading (Dakwah Team, 2015). Thus, it is a must of the people to always protect the ulama from various kinds of harm so that their existence can continue to spread goodness and peace in society.

Meanwhile, with the authority possessed, umara' can make policies that bring benefits to the society both in the economic, political, social and religious fields. In other words, da'wah and amar maruf nahi munkar really need power to actualize it (Zalikha, 2013). Therefore, the positive integration between ulama and umara' in the context of da'wah has always been relevant throughout the ages.

Even though the ulama and umara' have a very important position, especially in actualizing Islamic values and da'wah. Their relationship often has its ups and downs. The relationship between ulama and umara' is strongly influenced by the paradigm of power towards da'wah or religion. Umara' who has a secularistic paradigm tends to ignore the role of the ulama in carrying out his wheels of power or just take advantage of the ulama's character as a foothold to achieve power. When interests have been achieved, according to they are abandoned (Rasyid, 1999). Ulama are often treated like pushers for breaking down car. After the car on, the ulama are leaved on the road (Yafie, 1998). When the election season arrives, for example, almost all candidates for executive and legislative officials visit and help Islamic boarding schools that are cared for by the ulama because their existence in the community is considered as a voice barn.

In the context of Islamic civilization in the archipelago, ulama in the 
past were not used as political tools by umara' but Ulama were the political players. It is natural for them to think about and make policies that are oriented towards the development of Islamic da'wah, a policy that is born from their religious awareness and knowledge. Some examples include Sunan Giri, Nurudin Ar Raniri and Sunan Kalijaga. These three figures are not only known as ulama but also umara' who are very concerned about the implementation and development of Islamic da'wah in their territory.

The integration of ulama and umara' finally had big implications for the spread of Islam as the majority religion in the archipelago. The close relationship between the ulama and the pre-colonial umara'. This is a prominent characteristic in the historical trajectory of the archipelago (Jajat, 2013). Malay history describes in detail the important role of ulama in the Islamic empire at that time. However, after the entry of European colonizers into the archipelago, the relationship between ulama and umara' was separated in such a way that it influenced the formation of a more nationalistic secularistic Indonesian state system. The state is no longer seen as an entity for the sake of Islam but becomes a forum for all sects and religions in the name of democracy.

Now, the relationship between ulama and umara', as indicated by Daud Rasyid and Ali Yafie, is limited to formalistic and pragmatic interests. Ulama will be given space and respect if they support power. Otherwise they will be questioned if they have political thoughts and attitudes that are considered contrary to power. Not even a few of the Ulama and da'i are being persecuted for their da'wah activities. As experienced by Ustadz Abdul Shomad (republika, 2018), Ustadz Khalid Basalamah (kumparan, 2017), Ustadz Hanan At-Taki (voice.com, 2019), Ustadz Felix Shiaw (tempo.co, 2017) and so on.

The omission of opposition to Islamic da'wah activities in the society has made some people assess the criminalization of ulama. According to Riza, this assessment is getting stronger after the symptoms of 'sharp law' in opposition groups (some Islamic activists and Ulama) and 'lawlessness' against power support groups (Riza in detik.com, 2019). This phenomenon is interesting to study more deeply to find the pattern of the relationship between the two, especially from the historical aspect and its implications for the sustainability of Islamic da'wah in the current.

Another phenomenon is related to the clerical certification program or da'i certification. Some people view that this program intersects with the government's efforts in the fight against terrorism. While others consider 
that this program departs from Umara's suspicion of radical thinking developed by some da'i or ulama (bbc.com, 2019). The symbols of Muslim clothing are also the main targets that are considered in this program. For example, the prohibition of wearing cadar under the pretext as entrance of radicalism and Islamic fundamentalism (bbc.com, 2018). The various discourses and statements of umara' on the behavior of religious people have more strengthened the assumption that some circles of Muslims will have Islamophobia which is used to limit the practice of the religious teachings they believe in.

This assessment, for example, comes from Australian National University professor Greg Fealy, who captures that current powers are not friendly to diversity by carrying out a campaign of systematic suppression of Islamist groups. The Islamists, according to Greg, are trying to make Islamic law and values as center of public life and the structure of the state (suara.com). This issue in academic perspective, seen as intelectual issue that opened to be criticized and discussed. Thus, through these studies, it is hoped that they will be able to provide a space for dialectical thinking in an effort to answer the challenges of Islamic da'wah.

Studies with the theme of the relation between ulama and umara' have been written by previous researchers. Like Gozali (2016) who wrote about the relationship between ulama and umara' in Aceh. This study focuses on the relationship between ulama and umara' in Aceh during the era of Sultan Iskandar Muda. Furthermore, Bahrul Ulum (2019) which researches the synergy of ulama and Umara'. This research takes a case study in Jambi with the subject of SARA conflicts due to the installation of Allah's words on Christmas tree ornaments.

Another study was written by Doli Witro (2020) who also wrote about ulama and umara' in Indonesia. This study highlights Indonesia as a country with a majority Muslim population, but the country is not governed by Islamic rules as a whole like an Islamic country. It made differences and debates. This condition made dissensions among fellow Muslims with many cases of persecution and intimidation of preachers or clerics.

From a historical point of view, Yusri Akhimuddin's research (2012) tries to explore manuscript of relationship between ulama and umara' in Minangkabau in the 17th century in determining the beginning of Ramadan. This document becomes a manuscript that displays the relationship between the ulama and umara' in the settlement of the debate at the beginning and end of Ramadan. This study describes the intensive 
integration and relationship between ulama and umara' which has been going on for a long time. Other research was carried out by Fakhriati (2015) who examined Sirajuddin manuscript in the 19th century which reflected the conflict between ulama and umara'. This manuscript is seen as reflecting the differences in views between Sufi's Ulama and syar'i Ulama, the conflict between the ulama and umara' and the debate on the struggle of religion and the nation in Nanggroe Aceh Darussalam.

The relational study of ulama and umara' in Java was carried out by Umma Farida (2015) who researched the Islamization of Demak in the 15th century. Specifically, the researcher focuses on the collaboration of ulama and umara' in Islamic da'wah. The representation of umara' is depicted through the figure of Sultan Fattah and the ulama through the figure of Sunan Kalijaga. It was concluded that the ulama-umara' collaboration had also succeeded in carrying out a revolution in the fields of aqidah, worship, education, economy, military, government, art, law and social society.

The latest research was conducted by Ahmad Adi Suradi and Buyung Surahman (2020) who looked at the role of the kiai as ulama and umara'. More specifically, this study analyzes the implications for the world of Islamic boarding school education. It was concluded that the kiai as ulama and umara' became the prototype of the harmonization of religion and nation. On the one hand it has a positive impact, on the other hand it also brings negative perceptions from the public. Further research was carried out by Faizul Abrori (2020) which describes the urgency of collaboration between ulama and umara' in the local political democracy system in Situbondo Regency. It is concluded that the ulama are the morality figures and umara' are the policy holders who can strengthen the concept of civil society. Ahmad Zuhdi and Ivan Sunata (2020) strengthen research on the collaboration of ulama and umara' in an Islamic perspective. This research concludes that harmonization of ulama and umara' in narrating Islamic messages will strengthen efforts to build religion and nation.

In contrast to previous studies which tend to discuss theoretical, historical and local experience themes, this study specifically discusses the relation between ulama and umara' in a broader frame, as national by using empirical and historical data. Where, the focus of this research takes a point of view on the aspect of da'wah interests. Symptoms of problems such as persecution of Ulama and discourse on ulama certification as well as the relationship between ulama and umara' in the past which is reflected in 
figures such as Sunan Giri and Sunan Kalijaga are the data sources that are the basis for this research.

This study uses a qualitative approach with a descriptive method. The research is directed to answer the phenomenon of umara' antagonism towards ulama by using scientific documents such as books, journals and mass media as data sources. This research is expected to provide valuable information about the relationship between ulama and umara' in Indonesia, both past and reformed.

\section{RESULT AND DISCUSSION}

\section{The Strategic Role of Ulama and Umara' in the Development of Islamic Society}

Etymologically, ulama is taken from Arabic, namely from the word 'alim' which means people who have knowledge. The antonym of $1 \mathrm{~lm}(\mathrm{lmu})$ is ignorant or stupid. In the early days of Islam, ulama were identical with people who understood the religious sciences well and broadly (Qardhawi, $1417 \mathrm{H}$ ). In Indonesia, there are various titles that are attached to people who have the characteristics of being ulama. Each region has a different designation. For example, in Aceh it is called Tengku, in West Sumatra it is called Buya or Tuanku, in West Java it is called Ajengan, in Java it is called kyai and in Nusa Tenggara it is called Tuan Guru (Tim Compilation, 2003). The special mention that the community attaches to the ulama is an indication that the ulama have a special position in society. This privilege is even legitimized by Allah and the Messenger of Allah through several verses and hadiths of the prophet.

In terminology, the definition of ulama has been put forward by experts. However, according to Ade Wahidin, from the various definitions that exist, there has not been found a definition of ulama that satisfies and fulfills all the elements that are sub or parts thereof (jami') and has not also explained the elements that are not part of it (mani) (Wahidin, 2012). In general, it can be said that the main characteristic of the ulama lies in their mastery in broad religious knowledge, so that their personality reflects their syar'i knowledge. Namely practice knowledge and have a high fear of Allah SW'T.

From the various definitions of ulama, in essence the ulama are people who through their knowledge can produce fear of Allah SWT. The ulama inherit the knowledge of the prophets, so whoever takes the inheritance of that knowledge, he has taken his share perfectly as 
mentioned in the hadith narrated by Abu Darda (Sulayman, 1998). According to Imam Ghazali, clearly the high and noble position of scholars is mentioned in the Qur'an (Ghazali, 2011). In Qs Al-Mujdalam verse 11 it is explained that the position of the ulama has a high degree, so that it must be known by everyone in order to know that position and guard it (Arnawati, 2017). As there are various names for ulama in Indonesia, there are various ways to express the nobility of ulama in Indonesia. For example, lowering their heads when passing in front of the ulama, kissing the hands of the ulama, and some even drinking coffee or drinking water because they are believed to contain blessings.

Another ulama's glory lies in the mandate he carries as the successor of the prophets in spreading knowledge and guarding religion from misguidance. These tasks include: first, to convey the teachings of Islam according to Allah's commands. Second, explain God's teachings according to the commands of the Qur'an. Third, decide the case. Fourth, provide examples of practice (Shihab, 1994). These four tasks are automatically attached directly to the ulama' so that a ulama who does not carry out this task sincerely means that the ulama has betrayed the task assigned to him.

With all the glory they have, the ulama can be treated as number of stars that have various characteristics attached to themselves, including: first, having a wara' attitude, namely guarding against sinful acts. Second, have the commitment and courage to tell the truth, whatever the risks. Third, have compassion and love for fellow Muslims and easy to forgive. Fourth, stay away from opportunism and sycophants. Fifth, always draw closer to Allah by doing obedience such as prayer, fasting and reading the Qur'an. Fifth, have a serious attitude in exploring religious knowledge so that it can detail the arguments (Bajuri, 2019).

With all the idealism by a ulama, it is no exaggeration if the ulama is given the authority to explore the syara' laws in order to create a civilized and just legal order. On the other hand, the honor and position of the ulama must be well realized by the ulama themselves so that with that awareness the ulama do not humble themselves in front of anyone. Including in front of umara'.

The character of the ulama in front of the authorities must be firmly in favor of the truth. For this reason, Fethullah Gulen suggested that a ulama should not have too close a relationship with the rulers and conglomerates outside of his duties to convey amar ma'ruf nahi munkar. Because the Messenger of Allah said, "The worst of my ummah are the 
ulama who like to come to the rulers, whereas the best of the rulers are those who like to come to the ulama" (Gulen, 2011). The existing relationship between ulama and umara' is limited to da'wah and amar ma'ruf nahi munkar so that ulama are not trapped in worldly interests that make their tongues mute to state the truth.

Ulama have a strategic role in Indonesian society. The charisma and knowledge of the ulama are able to attract the sympathy of millions of people. That is why the ulama are considered important by Umara'. Not infrequently umara' who will make a policy to take into consideration the fatwa of the ulama. In responding to the 2020 COVID-19 pandemic, for example, the Jambi City MUI urges the public to comply with government instructions regarding the Ramadan worship (metrojambi.com, 2020). This appeal is important because MUI culturally its voice is sometimes more heard by the people than umara'. Another example, to reduce the number of abstentions every time a democratic party is held, both regionally and centrally, the MUI helps umara' by issuing a fatwa that prohibits abstaining from the fatwa delivered by MUI DIY. Choosing a legal leader is obligatory so that abstaining is illegal (detik.com, 2020). However, as a fatwa that is not binding, the fatwa in the community reaps the pros and cons. Some of these examples show that ulama's fatwas are needed to smooth out umara' policies, especially policies that require public support or the Muslim society.

Functionally, ulama cannot stand alone to realize goodness and da'wah in society. Ulama need other strengths so that the results of legal istinbat and da'wah can be applied in real life in the society. In this case, role of umara' becomes important in an effort to strengthen the Islamic da'wah narrative of the ulama. Etymologically, the term umara' in the Qur'an is called ulil amri, namely people who hold power, can make decisions and who handle various problems. According to Imam Mawardi, the main tasks of umara' are (1) to maintain the correct application of religion; (2) apply the law in every matter correctly; (3) protect state security; (4) enforce criminal law so that people's rights are protected; (5) maintain national borders with a good security system; (6) jihad against the enemy; (7) collect taxes and zakat according to the shari'a; (8) employ people according to their expertise and field; (9) distribute baitulmal; and (10) directly monitor the development and situation of the community (Mawardi, 2014).

All of these umara' duties are closely related to strengthening Islamic 
da'wah which is not only carried out with the principle of 'call out then leave' but umara' at the same time assisting and protecting the society as madh'u. Judging from the functions of the ulama and umara', it will be clear that both of them need synergy and integration in order to produce collaborative and transformative power in forming a just, prosperous civilization of society and in accordance with Islamic norms.

In order to unravel the problem of the relationship between ulama and umara' in this study, two main theories are used: first, the theory of division of the ulama according to Imam Ghazali. The theory is used to analyze the tendencies of the ulama towards power. Second, the theory of bigh politics and low politics used by Amien Rais to read the reality of umara' at this time.

According to Imam Ghazali's theory, the ulama are divided into two: the ulama of the hereafter and the ulama of the world (Ghazali, 2011). The ulama of the hereafter are ulama who fear Allah and are ascetic. Do not hesitate to tell the truth to anyone and whatever the risk. Meanwhile, world ulama are scholars who sell the verses of Allah and their influence for the benefit of the world. This type of ulama has no social concern and does not want to explain religious issues to the public objectively (Akmal, 2018). Imam Ghazali's theory is to confirm that even though the position of ulama is very high in Islam, sociologically not all ulamas use their position for the good of Islam, Muslims or the good of mankind in general.

Among them there are those who sell their knowledge and influence to gain position and power. In religious language, they are su' ulama, ulama who spread slander, sellers of religion with worldly treasures, ulama of division and ulama who are crazy about wealth (Hasyim, 1983). Therefore, many ulama's advice emphasizes the ulama's inheritors of the Prophet to be brave to erode polytheism and religious deviations committed by the authorities, whether the deviations are carried out individually and constitutionally (Mawardi, 2014). In carrying out this effort, the ulama will certainly face various challenges. Defending religion for religious motives does require struggle. Especially if the religious issue is in conflict with the interests of power.

The relationship between ulama and umara' today is facing an obstacle, especially when various narratives and accusations continue to be directed at Islam and Muslim. A phenomenon that has not occurred in the previous leadership era, especially after the reformation. For example, with the narrative of radicalism, umara' insists on monitoring and suspecting 
Islamic figures who are considered radical where the radical characteristics themselves do not have clear boundaries so they tend to have multiple interpretations. Meanwhile, through the development of this narrative, some Muslims consider umara' to be hostile to Muslims through the narrative and the formulation of certain programs.

Various issues of the relationship between ulama and umara' make an impression of an unhealthy relationship. The implication for the social life of Muslims is the emergence of a new dichotomy in the lives of Muslims such as the terms radical and moderate. A dichotomy which, according to Sabili magazine (2006), was spread or propagated by US intelligence and its allies to refer to Muslims who want to uphold Islamic law. According to Romli (2000), this dichotomy has actually appeared since the beginning of the conflict in the Middle East. The creation of the dichotomy of 'moderate Islam and radical/hardline Islam' is part of a devide politics to weaken the power of Muslims.

Refer to the theory put forward by Imam Ghazali, supporting for power programs that distort the ulama and Islamic teachings is impossible by hereafter Ulama. Moreover, the program to handle radicalism also involves ulama who are considered non-radical. This has the potential to divide the ulama and Muslims. This is injustice against Muslims. So if the authorities or functionary do wrong, should be avoided (Ghazali, 2011).

Referring to al Ghazali's theory, the ulama should be active in giving advice to the authorities so that they become religious helpers instead of distorting and misleading. The issue of radicalism should be localized objectively so that it is not wild and does not target the passion for practicing religion in a kaffah and correct manner. This is the function of the ulama's da'wah to Umara'. Even Al-Ghazali set an example by writing a special book containing advice to umara 'to be loyal to the Islamic way of life (Hasib, 2018).

When power is loyal to the Islamic view of life, harmony will be created between ulama and umara'. This relationship of course will give power to Islamic da'wah. This strengthening is doing by the application of Islamic leadership concept in the state dimension. According to Zuhdi, quoting Umar bin Khathab's statement that "Became a faqib before becoming a ruler", shows the necessity to place Islam and the state as two entities that are not opposites (Zuhdi, et al, 2020). This expression states that faqih in religious matters is an important recommendation before becoming a ruler or umara'. Where with faqib and the magnitude of the 
power possessed, then umara' will be able to parse various problems of the people correctly and far from tyranny.

Moreover, according to political theory, there are at least two types of politics, namely high politics and low politics (Day, 2005). The high and low quality of politics in a country is very depend on the attitude of the ruler or umara' as the administrator of the country. There are three characteristics of high politics, namely: first, realizing political office as a people's mandate that must be maintained properly. Second, every political position depends on accountability not only on the people or government institutions above it but also on responsibillity in the hereafter. Third, political activities must be based on the principle of ukhuwah. This high quality political principle will, of course, be very conducive to the development of da'wah and amar ma'ruf nahi munkar in a society. For this reason, according to Thohari (2005), ulama and islamic mass organizations must always play their political role as a form of da'wah and amar ma'ruf nahi munkar by influencing state policy so that it is in line with glorious goals and can defend a high-quality political culture.

However, in reality, politics with a high political character is still difficult to do. This happens not only in Indonesia, almost in most Islamic countries in the world. According to political research center LIPI (2008), in general, modern countries in the world today prefer low politics to highquality politics. This can be seen from the trend of relational tendencies between ulama and umara' in developing countries that are predominantly Muslim. In the context of the state, the strong relationship between ulama and umara' will strengthen the foundations of religion and the state. On the other hand, a less harmonious relationship between ulama and umara will lead to dynamics and often ends with the disintegration of the nation.

Historically, the strategic roles of ulama and umara' have been proven to be able to link various national interests. Harmonization of ulama and umara' manifests in various attitudes and actions that lead to common interests. The presence of the ulama became supporters of the umara' policy. And the existence of umara can strengthen leadership relations between various interests. Both of them play a role in preventing social disorder or social chaos among elements of the nation (Gozali, 2016).

$D a^{\prime} w a h$ activity as a form of amar maruf nahi munkar reflects an effort to form a life ecosystem based on good values. The diversity of society in various ways will be a power that can lead to the common good. It can be said that the strategic role of ulama and umara' is in the structural and 
cultural area. Where, in this case, the umara' holds the legal authority and the ulama holds the traditional authority (Akhimuddin, 2012). In other words, the ulama will strengthen the dissemination of the umara' policy and the umara' will strengthen the ulama's fatwa in the implementation process in the wider life space. In the da'wah narrative, this is what we know as constitutional da'wah, where the state becomes a space for strategic actualization of Islamic messages that will lead to the realization of an Islamic society.

The relationship between ulama and umara' represents the relational relationship between religion and the state. In the context of Indonesia, religion and state are inseparable spaces. This can be seen, among other things, through indications of the existence of legal transformation in Indonesia that takes into account religious values and messages (Witro, 2020). The relationship between religion and state as well as ulama and umara' is complementary and balancing. The application of sharia law in the context of people's lives will strengthen the rate of dissemination of Islamic messages in Indonesia. Therefore, the ulama are the umara' balancers in the policy-making process and the implementation of policies in the spaces of national life.

\section{Da'wah Ulama-Umara': Relations, Collaboration and Implications}

Indonesia is a country with a majority Muslim population. According to the 2010 population census, Indonesian Muslims account for 87.18 percent (Wahidin, 2012). The principles of Islamic teachings are believed and practiced in all levels of Muslim society. This is where collaboration or integration between ulama and umara' is needed in strengthening the values of Islamic teachings in the life of the society. The advice and da'wah of the ulama should be supported and even facilitated by umara'. Because umara ' needs ulama to legitimize the development program as well as support the development program.

The ulama's strategic role in the society must be fully realized by the umara'. Remembering their glory not only on their religious knowledge, but also on their attitude towards the world. Ulama's support or criticism of umara' must be free from worldly motives. This is where the importance of exemplary ulama who must be displayed in people's lives. On the other hand, when the ulama do not have good personality integrity and are even carried away by the currents of materialism, the ulama will lose their authority among the people and the umara'. Thus, their existence will be 
toyed with and will not be respected.

Ulama carry out the task of the prophets, namely spreading the message of Islam. The key to the success of the prophet Muhammad SAW lies in his success in setting an example for his people, both for the poor, rich, knowledgeable, business people, officials, farmers and so on. The task of the Prophet was very heavy, he started the movement of the people he led by example. This example, according to Mutawalli As-Sya'rowi (2007) is the key to the success of the Prophet's da'wah and the practice of his religious knowledge.

Viewed from the aspect of da'wah, the task of the ulama is actually related to umara'. Their role in social and political life can be divided into two, namely first, ulama who are not directly involved as government structural officials. Second, ulama who are involved in the government. Non-structural ulama play a role as community leaders, especially through scientific activities such as ta'lim assemblies or Islamic boarding schools. Through the scientific council that they founded, the role of the ulama as heirs of the prophet is not only able to explore sharia laws but also make maximum efforts so that Islamic teachings can be understood, fought for and applied in the lives of all levels of society. In addition, these nonstructural ulama also have the main obligation as controllers or advisers to umara'.

In state life, ulama are not just understand the religious arguments normatively, but also required to understand the global and regional political constellations. In this case, ulama not only understand the religious arguments conceptually but are also able to parse various people's problems more objectively, argumentatively and syar'i. In turn, the ulama are not only busy with the affairs of the branches of religion (furuiyyag), but also understand how to contextualize Islamic teachings as a solution to various problems in people's lives.

Meanwhile, ulama as government structural officials are those who occupy certain positions with the breadth and depth of Islamic knowledge they had. The position, for example, is qadhi (judge/court) or even head of state. In the state context, the position of the court in Islam is very important to ensure the enforcement of sharia law (Manan, 2015). Qadhi must have the capacity of ulama who are able to explore Islamic laws. Therefore, ulama is not just understand about judicial affairs but other requirements must also be fulfilled, such as baligh, intelligent and Muslim.

Both structural and non-structural ulama both play an important role 
in people's lives so that the knowledge they have must be actively utilized by the society and umara' for the benefit of the people and the establishment of Islamic da'wah. Therefore, the relationship between ulama and umara' must be good, both in the form of collaboration and integration, so that life does not limp, becomes balanced and leads to the common good (Republika, 2017). Practically, the relationship should not be bound by political or worldly interests that cause the orientation of Islamic da'wah to be marginalized. However, the relationship must be built on the pleasure of Allah SWT in order to achieve the benefit of society.

Sociologically, the relationship between ulama and umara' is dynamic. Ulama as the main actors of Islamic da'wah are divided into two: first, ulama who are pro-power and second, ulama who are against power. That classification is not appropriate but merely to describe the existing reality. This can be seen from the reality of state life which reflects the dynamics between ulama and umara'.

This dichotomy appears in the historical trajectory of the Indonesian nation. For example, at momentum for the contention of democracy, both in the presidential and legislative elections. At a moment like this, ulama can be said to be the people's 'voice magnet' that can be used to attract support. In the 2019 election, for example, no less than 35 Habaib and ulama from East Java, Central Java and Banten gave support to the Joko Widodo-Ma'ruf Amin pair (Kumparan, 2018). On the other hand, ulama who became the power opposition in the 2019 elections such as UAS, Aa Gym, UAH and so on supported the Prabowo-Sandi pair (jpnn, 2019).

The phenomenon of ulama supporting the umara' candidate in a system that tends to apply a low politics culture is actually quite risky, especially it can cause a person's religious independence to be doubted. That is the reason, why ulama in the past kept their distance and set firm boundaries in their relationship with the authorities to prevent distortions of ulama's independence towards political authorities in the process of exploring and enacting laws.

The inclusion of the ulama into practical political activities then raised problems for their da'wah activities, especially for ulama who did not support the incumbent. Individually, some of them experience persecution, become targets of buzzers and other violent attempts. In addition, there is also a discourse on clerical certification which marks the rivalry between ulama and umara'. The discourse on ulama certification is still a problem that the government has not been able to solve. This phenomenon could 
lead to a conflict between the ulama and the umara' which led to the disintegration of the nation.

Historically, the ulama-umara' conflict as a rivalry is caused by the ulama's assessment of umara' who is considered to have out of religious values and norms. Or it could also be caused by an act of disobedience with his power. Meanwhile, with its simplicity and influence of Ulama's fatwas have social impact on people's lives. This phenomenon makes Umara' often considered 'use the ulama' with the purpose of power. So, not a few ulama make political 'deals' with certain positions.

In the early days of Islamic history in the archipelago, the relationship between ulama and umara' occurred dynamically. There are ulama who serve as qadhi, become opposition and even sycophants. Some of the strategic roles occupied by the ulama in the government at that time were dominantly built on respect for the figure and knowledge of the ulama. Not on pragmatic interests as in the era of independence and reform. This situation allows them to freely formulate policies based on their religious knowledge. With a strong system and personality, the ulama are not trapped in misleading political agreements. So that the thoughts and policies taken by the ulama represent the breadth of their religious understanding which is based on the interests of the ummah.

At the beginning of the pre-colonial period, the role of the ulama was built through legal institutions that played the role of Qadhi. The judiciary is one of the most important institutions that provide legitimacy for ulama to enforce Islamic law. Even this Qadhi institution was increasingly established in the 17th century, especially in the Islamic Kingdom of Aceh and Banten (Jajat, 2013). This position is a necessity for a country that uses Islam as an ideology to provide direction in the development of a whole human being.

The role of the ulama during the Islamic empire in government was different from their role in the reform era. Even though ulama sometimes sit in government, their position is not as strong as before. Expensive political and social costs make the ulama who sit in the current government are often trapped in political deals and represent the interests of supporting parties and investors. Finally, when sitting in the seat of power, the ulama find it difficult to make policies that represent their religious and moral understanding. This is where the tough task of the ulama is to always maintain sincerity so as not to get trapped into being su' ulama (Mahfud MD, 1999). 
Facing such conditions, it is interesting to notice quote from Imam Ibn al-Jauzi. According to him:

"If scholars and knowledgeable people do not have the power and authority in front of the authorities when they enter the middle of power, it is feared that they will be carried away by the current of improper and unlawful power. While they themselves are not able to force the rulers to leave tyranny. Finally, their knowledge becomes fragile in the axis of power. they are no more honorable than soldiers in the ruler's palace" (Jauzi, 2016).

This concern is very relevant, especially if you look at the reality of ulama who accept something that before taking office was rejected or on the contrary rejects something that was previously accepted in order to achieve power ambitions. In addition, the absence of an institution that structurally gives strong authority to ulama to make policies, causes the current existence of ulama to have a weak position. Especially in controlling power and taking policies oriented to $d a^{\prime} w a h$ and the actualization of Islamic teachings as a system of life. Furthermore, the high position of the ulama is sometimes lowered by programs that weaken the position of the ulama, such as the discourse on the certification of the ulama and the fact that there are many acts of persecution of the ulama.

It is different, for example, with the role of the ulama during the Islamic empire. Besides them, they are ulama culturally, but some of them have the authority or power that can be used as a force for da'wah and Islamic interests. In a broader context, the spread of Islamic da'wah in the archipelago by figures known as walisongo, it turns out that it wasn't just a personal initiative. The arrival of these ulama, some of whom later became qadhi, umara' or kings of Islam, was actually initiated by the Ottoman Sultan Muhammad I who came to power in 1394 AD. The formation of this institution is started by a report from Gujarat (India) trader that Muslim in Java is still a bit.

In the concept of a secular state that separates religion from the state, religion is only given freedom culturally but not structurally. In this case, religion becomes a teaching entity to be practiced but seems to be negated in the structural realm of the state. Conceptually, Islam has a different teaching character from other religions. Where there are many Islamic teachings whose implementation requires the state as a reinforcement as well as a space for the actualization of da'wah.

There are various motives when ulama enter the realm of power. This 
is reflected in his work when running the wheel of power. In the era of the Islamic empire, when the ulama collaborated and integrated with power, it was more based on an awareness of the importance of power as a tool for spreading and implementing Islam. Therefore, among these ulama there were those who did not become mere royal advisors but instead established kingdoms such as Sunan Giri as one of the important figures in the spread of Islam in Java. His work is not only known as a ulama but also umara '. Besides being known as an influential ulama, Sunan Giri is also a successful political figure by acting as an umara' or Islamic ruler who makes Islamic da'wah as his main mission. This political position can be seen from the title he holds, namely Prabu Satmata. Sunan Giri's major contribution to da'wah is to spread Islam by sending his students to various corners of the archipelago to teach Islam, for example to the islands of Bawean, Ternate and Madura (Anita, 2014).

In the current context, sending students to study religion more deeply in various Islamic countries in the Middle East can be said to be a positive step for strengthening Islamic da'wah in the country. However, this support needs to be strengthened with practical, moral and material support from umara'.

Besides Sunan Giri as a role model in the integration of da'wah and umara', there is another figure, namely Sunan Kalijaga. Sunan Kalijaga's role in helping umara' occurred when the Demak kingdom was founded until the sultanate ended. Sunan Kalijaga's role as a ulama was very important in determining the style of government and politics at that time. In fact, apart from being an expert in religious matters (faqih), Sunan Kalijaga is also an expert in urban planning. Thus, every city built by the Sultan by involving Sunan Kalijaga must have four buildings as its trademark, namely: the square, the palace palace, the banyan tree and the mosque.

The da'wah collaboration between the ulama and umara' during the time of Sunan Kalijaga was represented in the making of royal policies concerning the practical life of the people. In this case, da'wah is not only calling on people to convert to Islam, but also taking an active role in carrying out actions or policies that can soften people's hearts, such as meeting public needs. At that time, the public need that was considered very important was the availability of water for both family needs and agricultural irrigation. The reason is that Demak is an area that often faces the dry season. The control of water resources by the Sultan who was supported by Sunan Kalijaga succeeded in attracting the sympathy of the 
people so that it had a major influence on the success of Islamic da'wah on the island of Java. In the history of the Prophet's da'wah, the control of people's livelihoods such as water is considered very strategic and even became the key to Islam's victory in the battle of Badr. With the control of the area that became the source of water, namely the Badr area, the Quraysh infidels lost access to their water needs.

Based on these historical and empirical facts, it can be seen that the relationship between ulama and umara' has quite influential implications for strengthening Islamic da'wah at state life. If during the Islamic empire, the relation between the ulama and the umara' was collaboration and even integration based on an integralistic relationship, during the colonial period and afterward, the relation between the ulama and the umara' was more of a secularistic and pragmatic relationship. This relationship then has implications for a different atmosphere of Islamic da'wah. Integralistic relations tend to strengthen and strengthen the mission of Islamic da'wah in society. Ulama through the structural institutions under their control play an important role in controlling the development of Islamic da'wah through the various policies they make. Logistical and budgetary support will further strengthen the position of Islam as a da'wah religion.

It is different from the relation between ulama and umara' which is built on a pragmatic secularistic paradigm. The relationship between the two is more about each other's interests which sometimes do not make people's problems a priority agenda to be resolved. Pragmatic secularistic relations tend to use religion as a foothold to get positions. Finally, the ulama who should have been placed in a strategic position to build the religiosity and religious obedience of their people have actually been used as a tool to justify the ruler's policies that are not in line with the interests of Islamic da'wah.

Furthermore, it seems that the ulama are conditioned to submit to power with the programs they make. The goal is to protect power from constructive thoughts that are considered dangerous or interfere with the policies of the oppressor. The weight of the task of these scholars is in line with their high position if they are consistent with the truth. This is as explained in the hadith of the Prophet that 'the most important jihad is to declare the sentence of justice before the oppressor' (Narrated by Abu Dawud, At Tarmidhi). In addition to the teachings to obey the leader, Islam also instructs its people to advise the leader or umara' when making deviations or making policies that are detrimental to society and the state. 
(Al Qardhawi, 1995).

The attitude of the ulama, both culturally and structurally, is important to always accompany and control the umara' in running the wheel of power while being careful not to get caught up in the interests of power. Because power, as the Lord Acton said, that 'power tends to corrupt; and the absolute power tends to absolutely corrupt. That power always tends to deviate (corrupt); and an absolute power must tend to deviate (corrupt) in the absolute sense. Therefore, the criticisms conveyed by scholars, academics and the media play a role so that this tendency can be directed at the benefit of the people and not 'overweight' with bad qualities.

Even though ulama and umara' face dynamic relations in every era, both of them can open up a space for dialogue for the benefit of the wider community. Authoritarianism and violence, whether carried out by the authorities or civilians, will only exacerbate the problem. In addition, these methods will make the image of Islam and Muslims worse through the exploitation of media coverage (Al Qardhawi, 2010). The ulama-umara' relationship across Indonesian history displays an integralistic state-religion relationship. This relationship will strengthen the dissemination of Islamic messages that aim at the realization of a good life. In the historical context, the existence of the ulama strengthened the umara' policy in the policymaking process both during the royal, pre-colonial and post-colonial times. Ulama and umara' in the context of the state represent a strategic and significant role in Islamic da'wah activities.

Practically, in state life, the relation between ulama and umara' can be categorized into three forms, namely: ulama who cooperate with umara', ulama who keep their distance from umara' and ulama who are in opposition to umara' (Witro, 2020). All three show dynamic relations in the context of state life. What is important to understand is that in any position and role, the presence of ulama is important to strengthen policies and keep the continuity of Islamic da'wah.

The history of the da'wah of the Prophet Muhammad shows the fact that Islamic da'wah activities cannot be separated from the role of ulama and umara. In the Medina Charter, for example, the Islamic da'wah relationship takes place in the midst of diversity. The Prophet SAW made the Medina Charter as the basis for fostering harmony between various elements of a diverse nation. In this position, the Prophet Muhammad acted as a religious leader (ulama) and state leader (umara). Thus, the 
significance of Islamic da'wah is reflected in the process of internalizing and actualizing Islamic values in state life (Rustandi \& Sahidin, 2019).

The relationship and collaboration between ulama and umara' in an effort to disseminate Islamic messages has implications for various dimensions of community life. In this case, the strategic positions of ulama and umara' are complementary and balancing. This relational implication will be seen in the realization of an integralistic relationship between religion and the state. Thus, Islamic da'wah is not only limited to changing the conditions, thoughts and actions of personal da'wah objects, but also seeks to change the thoughts and actions of da'wah objects at the state level. The state as a space for the actualization of Islamic da'wah becomes a strategic space in efforts to disseminate, internalize and actualize Islamic teachings that are oriented to the common good. This can be seen from the strengthening of knowledge, rituals, beliefs, experiences and commitments to Islam and the state in the reality of people's lives.

\section{CONCLUSION}

The success of Islamic da'wah is very dependent on good relations between ulama and umara'. Because the ulama and umara' have strong social and political capital. If the two are synergized and even integrated, both socially and politically, it will result in a major change in a more religious and religious society. This means that the purpose of da'wah is to form a society of believers and to practice the teachings of Islam will be realized.

The relationship between ulama and umara' that is synergistic and not limited to formalities in a state that ignores part or all of religious teachings will be difficult to realize. Therefore, there needs to be a common awareness of Muslims to unite and synergize to create high politics, namely politics that makes Islamic values an inspiration and aspiration for a better order of community life. The political process and da'wah that synergize between ulama and umara' become a force that will bring goodness in the lives of the people, nation and state. Therefore, the harmonious relationship between ulama and umara' must be built on theological and sociological awareness and the obligation of Islamic da'wah in spreading universal messages from Islamic teachings both in the individual and institutional spheres, both in the context of personal and state actors. 


\section{REFERENCES}

Abrori, F. (2020). Uregensi Ulama dan Umara' dalam Sistem Demokrasi Politik Lokal Kabupaten Situbondo, At-turost: Journal of Islamic Studies, $7(1)$, 1-11. https://ejurnal.stainh.ac.id/index.php/jurnal/article/view/18.

Akhimuddin, Y. (2012). Naskah [Asal Khilaf Bilangan Taqwim]: Relasi Ulama-Umara' di Minangkabau Abad ke-17 dalam Penetapan Awal Ramadan, Manuskripta, 2(1), 79-101. DOI: https://doi.org/10.33656/manuskripta.v2i1.27.

Akmal, A. M. (2018). Konsepsi Ulama Dalam Alquran, Ash-shahabah: Jurnal Pendidikan dan Studi Islam, 4(2), 174-182. http://journal-uimmakassar.ac.id/index.php/ASH/article/view/225.

Al Qardhawi, Y. (1995). Fatwa-Fatwa Kontemporer. Jakarta: Gema Insani Press

Anita, D. E, (2014). Walisongo: Mengislamkan Tanah Jawa, Suatu Kajian Pustaka, Wahana Akademika, 1(2), 243-266. DOI: 10.21580/wa.v1i2.815.

Arnawati, A. (2017). Kedudukan dan Peran Ulama dalam Al Qur'an (Studi Komparatif dalam Tafsir Al-Qur'an Al-Azim dan Tafsir Fi Zilal AlQur'an), Jurnal al-Fath, 11(1), 1-20. DOI: http://dx.doi.org/10.32678/alfath.v11i1.875.

As-Sya'rowi, M. (2007). Anda Bertanya Islam Menjawab. Jakarta: Gema Insani Press.

Bajuri, M. (2019). Ulama, Petunjuk dan Penentu Kebaikan Umat, Jurnal Al Wa'i, Nomor 397 Tahun XXXIV Shafar $1441 \mathrm{H}$.

Day, S. B. (2005). Hubungan Politik Dan Dakwah, Mediator, Jurnal Komunikasi, MediaTor: Jurnal Komunikasi, 6(1), 7-16. DOI: https://doi.org/10.29313/mediator.v6i1.1171.

Fakhriati. (2015). Refleksi Konflik Antara Ulama Dan Umara' Pada Abad Ke-19M; Telaah Atas Naskah Sirajuddin, Jurnal Masyarakat dan Budaya, 17(1), 37-50. DOI: https://doi.org/10.14203/jmb.v17i1.121.

Farida, U. (2015). Islamisasi Di Demak Abad Xv M: Kolaborasi Dinamis Ulama-Umara' dalam Dakwah Islam di Demak, At-Tabsyir: Jurnal Komunikasi Penyiaran Islam, 3(2), 299-318. DOI: 10.21043/attabsyir.v3i2.1649.

Ghazali, I. (2011). Ihza Ulumuddin, Terj. Muh. Zuhri. Semarang: CV Asyifa' 
Gozali. (2016). Hubungan Umara' Dan Ulama Dalam Membentuk Kehidupan Sosio-Relijius Di Aceh Darussalam Masa Sultan Iskandar Muda, Jurnal Penelitian Hukum De Jure, 16(2), 173-185. DOI: http://dx.doi.org/10.30641/dejure.2016.V16.173-185.

Gulen, M. F. (2011). Dakwah. Jakarta : Penerbit Republika.

Hasib, K. (2018), Konsep Siyasah Dan Adab Bernegara Menurut Imam AlGhazali, Falasifa: Jurnal Studi Keislaman, 8(1), 1-17. DOI: https://doi.org/10.36835/falasifa.v8i1.35.

Hasyim, U. (1983). Mencari Ulama Pewaris Para Nabi: Selayang Pandang Sejarah Para Ulama. Jakarta: Bina Ilmu.

Jajat, B. (2013). Ulama dan Kekuasaan : Pergumulan Elit Politik Muslim dalam Sejarah Indonesia. Jakarta: Mizan.

Jauzi, I. (2016). Shaidul Khatir: Cara Manusia Cerdas Menang dalam Hidup. Jakarta: Maghfirah Pustaka

Mahfud, M. MD. (1999). pergulatan politik dan bukum di Indoenesia. Yogyakarta: Gamamedia.

Manan, A. (2015). Etika Hakim Dalam Penyelenggaran Peradilan. Jakarta: Prenada Media.

Mawardi, I. (2014). Abkam As Sulthaniah. Jakarta: Qisthi Press.

Rasyid, D. (1999). Islam dan Reformasi. Ponpes Unggulan al Makmuriyah.

Romli, A. S. M. (2000). Demonologi Islam: Upaya Barat Membasmi Kekuatan Islam: Jakarta: Gema Insani Press.

Rustandi, R., \& Sahidin, S. (2019). Analisis Historis Manajemen Dakwah Rosulullah Saw dalam Piagam Madinah, Tamaddun: Jurnal Sejarah dan Kebudayaan Islam, 7(2), 362-387. DOI: 10.24235/tamaddun.v7i2.5503.

Sulaymân, A. D. (1998). Sunan Abu Dawud Vol. 1. Beirut: Dar al Fikr.

Suradi, A. A., \& Surahman, B. (2020). Kiai's role as ulama and umara: Implications to the pesantren education, Masyarakat, Kebudayaan dan Politik, $\quad 33(2), \quad 202-211 . \quad$ DOI: http://dx.doi.org/10.20473/mkp.V33I22020.202-211.

Shihab, Q. (1994). Membumikan Al-qur'an. Bandung: Mizan.

Thohari, H. Y. (2005). Muhammadiyah dan Pergulatan politik Islam Modernis. Jakarta: PSAP.

Tim Dakwah Pesantren. (2015). Kumpulan Tanya Jawab Keagamaan. Yogyakarta: PISS KTB.

Tim Penyusun. (2003). Ensiklopedia Islam. Jakarta: PT Ikhtiar Baru.

Ulum, B. (2019). Sinergitas Ulama dan Umara': Artikulasi dalam 
Penyelesaian Kasus Sara tentang Pemasangan Lafaz Allah pada Ornamen Pohon Natal di Hotel Novita Jambi, Al-Daulah: Jurnal Hukum Dan Perundangan Islam,9(1), 118-141. DOI: https://doi.org/10.15642/ad.2019.9.1.117-141

Wahidin, A. (2012). Konsep Ulama Menurut al Qur'an (Studi Analitis atas Surat Fathir ayat 28), Al Tadabur: Jurnal Ilmu al-Qur'an dan Tafsir, 1(1), 38-56. DOI: http://dx.doi.org/10.30868/at.v1i01.168.

Witro, D (2020). Ulama and Umara' in Government of Indonesia: A Review Relations of Religion and State, Madania: Jurnal Kajian Keislaman, 24(2), 135-144. DOI: http://dx.doi.org/10.29300/madania.v24i2.3778.

Yafie, A. dkk. (1998). Mutiara Nahdhatul Ulama'. Jakarta: Fatma Press.

Zalikha. (2013). Dakwah Dan Kekuasaan (Perspektif Historis), Jurnal AlBayan: Media Kajian dan Pengembangan Ilmu Dakwah, 19(2), 20-30. DOI: http://dx.doi.org/10.22373/albayan.v19i28.103.

Zuhdi, A., dan Sunata, I. (2020). Kolaborasi Dakwah Ulama dan Umara', Ishlah: Jurnal Ilmu Ushuluddin, 2(1), 32-51. DOI: https://doi.org/10.32939/ishlah.v2i1.12. 
